\title{
KEWARGANEGARAAN GANDA ANAK DALAM PERKAWINAN CAMPURAN DAN IMPLIKASINYA DALAM HUKUM PERDATA INTERNASIONAL
}

\author{
Leonora Bakarbessy \\ Sri Handajani \\ Fakultas Hukum Universitas Airlangga Surabaya \\ e-mail: leonora@fh.unair.ac.id
}

\begin{abstract}
ABSTRAK
Dengan diundangkannya Undang-Undang No. 12 Tahun 2006 tentang Kewarganegaraan Republik Indonesia yang memberlakukan dua kewarganegaraan bagi anak-anak hasil perkawinan campuran. Berdampak dalam Hukum Perdata Internasional dimana mereka tunduk pada dua yurisdiksi dari dua Negara yang berbeda. Permasalahan yang timbul dalam hukum perdata internasional yakni hukum dari negara mana yang berlaku terhadap status personal mereka. Solusi bagi anak yang berkewarganegaraan ganda yaitu bila ia mempunyai habitual residence di Indonesia yang jatuh bersamaan dengan salah satu kewarganegaraannya yaitu Indonesia, maka hukum Indonesia berlaku bagi status personalnya. Bagi yang mempunyai habitual residence di luar negeri maka dia diperlakukan sebagai orang asing. Hak waris atas rumah dan tanah dapat diturunkan misalnya dari hak milik menjadi hak pakai.
\end{abstract}

Kata Kunci: perkawinan campuran, kewarganegaraan ganda, anak.

\begin{abstract}
The promulgation of Law No 12 Year 2006 about Republic Indonesia of Citizenship executing dual citizenship to children of mixed marriage gives impact to International Civil Law in which they have to obey to the law of two different countries. The raising problem in the International Civil Law is which law can be used to give their personal status. The solution used by children who have dual citizenship is since they have habitual residence in Indonesia automatically they are the citizenship of Indonesia and the law of Indonesia used to give their personal status. On the other hand, those who have habitual residence in overseas country, they are considered as foreigners. Inheritances rights of land and house are the proprietary can be changed become use rights.
\end{abstract}

Keywords: mixed marriage, dual citizenship, children.

\section{PENDAHULUAN}

Globalisasi informasi, ekonomi, pendidikan dan transportasi menyebabkan batas negara bukan lagi halangan untuk berinteraksi. Hal tersebut berdampak semakin meningkatnya perkawinan antar bangsa yang terjadi hampir di seluruh dunia. Perkawinan pasangan beda kewarganegaraan yang paling banyak terjadi adalah, perkenalan melalui internet, kemudian teman kerja atau teman bisnis, berkenalan saat berlibur, bekas teman sekolah atau kuliah dan sahabat pena (Nuning Hallet, www.snb.or.id).

Dari hasil survey tersebut di atas dalam Tahun 2002 sampai dengan 2004 di Kantor Catatan Sipil Jakarta tercatat 878 perkawinan campuran yang tercatat disana (Nuning Hallet, www.snb.or.id), angka tersebut akan meningkat bila ditambah dengan pencatatan perkawinan campuran yang dilangsungkan di daerah- daerah lain di seluruh Indonesia. Dengan banyaknya terjadi perkawinan campuran di Indonesia, sudah seharusnya perlindungan hukum bagi perkawinan campuran ini bisa diakomodir dengan baik dalam perundang-undangan di Indonesia.

Di Indonesia perkawinan campuran yang terjadi dapat dalam dua bentuk yaitu: Pertama, Wanita Warga Negara Indonesia (selanjutnya disebut WNI) yang menikah dengan pria Warga Negara Asing (selanjutnya disebut WNA); dan Kedua, Pria WNI menikah dengan wanita WNA. Faktor perbedaan kewarganegaraan di antara para pihaklah yang kemudian membedakan suatu perkawinan campuran dengan perkawinan yang bersifat intern. Perbedaan kewarganegaraan tersebut tidak saja terjadi saat awal dimulainya suatu perkawinan campuran, tetapi dapat berlanjut setelah terbentuknya suatu keluarga perkawinan campuran. 
Undang-Undang Kewarganegaraan Indonesia No. 62 Tahun 1958 (yang selanjutnya disebut UU Kewarganegaraan Lama) maupun Undang-Undang Kewarganegaraan Indonesia No. 12 Tahun 2006 (yang selanjutnya disebut UU Kewarganegaraan Baru) tidak memberikan status kewarganegaraan Indonesia secara otomatis bagi wanita WNA yang menikah dengan pria WNI, tetapi apabila wanita WNA tersebut ingin menjadi WNI maka ia harus mengajukan permohonan resmi sesuai peraturan yang berlaku. Demikian juga wanita WNI yang menikah dengan seorang pria WNA dapat tetap mempertahankan kewarganegaraan Indonesia, bila ia hendak mengikuti kewarganegaraan suami menjadi WNA, maka wanita tersebut diharuskan untuk mengajukan permohonan sesuai peraturan yang berlaku seperti tertuang dalam Pasal 7 dan 8 UU Kewarganegaraan Lama, dan Pasal 26 UU Kewarganegaraan Baru. Hal yang demikian itu dapat menimbulkan perbedaan kewarganegaraan dalam keluarga suatu perkawinan campuran.

Perbedaan kewarganegaraan tidak saja terjadi antara pasangan suami istri dalam suatu perkawinan campuran, tetapi juga terjadi pada anak-anak hasil perkawinan campuran. Menurut UU Kewarganegaraan Lama, kewarganegaraan untuk anak hasil perkawinan campuran mengikuti kewarganegaraan ayahnya, apabila anak yang lahir dalam suatu perkawinan campuran dari ibu WNI dan ayahnya WNA, anak tersebut secara otomatis menjadi WNA, sehingga terjadi perbedaan kewarganegaraan antara anak yang lahir tersebut dengan ibunya yang WNI.

Perbedaan kewarganegaraan antara anak WNA dengan ibunya WNI menimbulkan banyak masalah hukum, baik selama masa perkawinan campuran itu berlangsung maupun setelah putusnya perkawinan campuran. Terdapat banyak kasus yang muncul, dimana UU Kewarganegaraan Lama tidak dapat melindungi anak-anak yang lahir dari seorang ibu WNI suatu perkawinan campuran, teristimewa saat putusnya perkawinan dan anaknya yang WNA harus berada dalam pengasuhan ibunya WNI serta bertempat tinggal di dalam Negara Indonesia yang notabene merupakan negara ibunya sendiri.

Dengan diundangkannya UU Kewarganegaraan Baru, aturan ini memberikan kewarganegaraan ganda, hanya terbatas pada anak-anak hasil perkawinan campuran sampai anak tersebut berusia 18 tahun atau sudah kawin, setelah itu ia harus memilih salah satu untuk menjadi kewarganegaraannya. Adapun status kewarganegaraan ganda yang dianut dalam UU Kewarganegaraan Baru merupakan terobosan untuk mengatasi permasalahan yang timbul dalam perkawinan campuran, maupun setelah putusnya perkawinan campuran, dimana terdapat perbedaan kewarganegaraan antara orangtua dan anak-anak hasil perkawinan itu.

Seiring dengan melekatnya kewarganegaraan ganda terbatas pada anak hasil perkawinan campuran, maka anak tersebut tunduk pada dua yurisdiksi dari dua negara yang terkait kewarganegaraan dari kedua orangtuanya, sehingga menimbulkan permasalahan hukum di bidang Hukum Perdata Internasional, yaitu hukum dari negara mana yang berlaku atas status personalnya. Suatu contoh yang dapat dikemukakan disini misalnya di Indonesia, perkawinan baru dapat dilangsungkan apabila pihak wanita telah mencapai umur 16 tahun sesuai yang diatur Undang-Undang No. 1 Tahun 1974 tentang Perkawinan (selanjutnya disebut UUP) Pasal 7. Seandainya anak tersebut mempunyai kewarganegaraan ganda, maka syaratsyarat perkawinan anak tersebut tunduk pada hukum dari negara mana, apakah hukum Negara Indonesia atau asing (Pasal 7 UUP).

Masalah lainnya yang timbul berkaitan dengan status anak yang berkewarganegaraan ganda yaitu mengenai warisan yang ditinggalkan ayah atau ibunya yang berkewarganegaraan Indonesia. Menurut teori Hukum Perdata Internasional untuk menentukan status anak dan hubungan antara anak dan orangtua perlu dilihat lebih dahulu, perkawinan orangtuanya sebagai persoalan pendahuluan, apakah perkawinan perkawinan orangtuanya sah, bila anak lahir dalam suatu perkawinan yang sah maka bila salah satu atau kedua orangtuanya meninggal maka anak adalah ahi waris.

Berdasarkan yurisprudensi dalam Hukum Perdata Internasional baik di Belanda maupun di Indonesia, hukum yang berlaku mengenai warisan adalah hukum nasional dari pewaris. Terkait kewarganegaraan ganda anak dari hasil perkawinan campuran, bila salahsatu orangtuanya yaitu ibunya WNI atau ayahnya WNI meninggal dunia, tentunya anak-anaknya adalah ahli waris ibu atau ayahnya yang adalah WNI.

Di Indonesia, seseorang yang berstatus WNA dibatasi untuk memperoleh hak-hak tertentu, seperti yang diatur dalam Undang-Undang Pokok Agraria No. 5 Tahun 1960 (yang selanjutnya disebut UUPA), dalam Pasal 21 ayat 2 dikatakan orang asing tidak dapat mempunyai hak milik, pada ayat 3 juga melarang seorang yang mempunyai kewarganegaraan ganda mempunyai hak milik.

Bila undang-undang di Indonesia membatasi hakhak seseorang yang mempunyai kewarganegaraan ganda, dan pada sisi lain UU Kewarganegaraan Baru 
mengakui keberadaan seorang anak dengan status kewarganegaraan ganda maka timbul pertanyaan, bagaimana seorang anak dapat merealisasi haknya untuk mewaris, jika salah satu dari orangtua yang berkewarganegaraan Indonesia meninggal dunia.

\section{PERMASALAHAN}

Pengakuan mengenai adanya kewarganegaraan ganda dalam UU Kewarganegaraan Baru, bertujuan menghapus diskriminasi dan menjamin hak asasi manusia terutama terhadap wanita dan anak-anak. Berdasarkan latar belakang seperti tersebut di atas, maka permasalahan yang akan dibahas yaitu, hukum dari negara mana yang berlaku atas status personal dari anak yang berkewarganegaraan ganda tersebut, serta bagaimanakah realisasi hak waris anak yang berkewarganegaraan ganda dari ayah atau ibunya yang berkewarganegaraan Indonesia.

\section{PEMBAHASAN}

\section{Hubungan antara Kewarganegaraan Seseorang dengan Status Personal}

Status personal berasal dari madzab Italia yang membagi kaidah-kaidah Hukum Perdata Internasional dalam 3 kelompok yaitu: statuta personalia, statuta realia dan statuta mixta. Statuta personalia adalah kelompok kaidah-kaidah yang mengikuti seseorang kemanapun ia pergi; statuta realia adalah kelompok kaidah-kaidah yang mengatur tentang benda tetap; sedangkan statuta mixta (campuran), adalah kelompok kaidah-kaidah yang mengatur tentang bentuk dari suatu perbuatan hukum (Saragih Djasadin, 1974:33-35).

Sistem Hukum Perdata Internasional yang berlaku di Indonesia sampai sekarang merupakan sebuah warisan dari sistem Hukum Perdata Internasional yang ditinggalkan oleh Pemerintah Hindia Belanda berdasarkan asas konkordansi, dimana pengaturan mengenai status personal terdapat dalam Pasal 16 Algemene Bepalingen Van Wetgeving (selanjutnya disebut $\mathrm{AB}$ ) yang berasal dari Pasal $6 \mathrm{AB}$ Belanda yang menyalin lagi dari Pasal 3 ayat 3 Code Civil Perancis (Sudargo Gautama 1, 1981:2). Pasal 16 AB menyatakan Ketentuan-ketentuan perundangundangan mengenai status dan wewenang orang-orang tetap mengikat Warga Negara Indonesia jikalau mereka berada di luar negeri.

Berdasarkan pasal $16 \mathrm{AB}$ tersebut, Indonesia menganut prinsip nasionalitas atau kewarganegaraan dalam menentukan status personal seseorang. Hal ini berarti bagi WNI yang berada di luar negeri, sepanjang mengenai hal-hal yang terkait dengan status personalnya, tetap berlaku hukum nasional
Indonesia. Sebaliknya menurut yurisprudensi, bagi orang-orang asing yang berada di dalam wilayah Republik Indonesia dipergunakan hukum nasional mereka sepanjang hal tersebut termasuk dalam lingkup status personal antara lain mengenai perkawinan dan perceraian, pembatalan perkawinan, perwalian, kewenangan untuk melakukan perbuatan hukum, soal nama, soal status anak di bawah umur dan lain-lain. Karena Pasal 16 AB merupakan kaidah penunjuk sepihak (eenzijdige verwijzingregels) sehingga dalam praktek ditafsirkan secara timbal balik (tweezidige). Berbeda dengan negara-negara Common Law dimana status personal seseorang dinilai menurut hukum domisilinya.

\section{Status Kewarganegaraan Anak dalam Perkawinan Campuran: Kewarganegaraan Anak menurut Undang-Undang Kewarganegaraan Lama}

Dalam UU Kewarganegaraan Lama dianut asas kewarganegaraan tunggal. Dimana kewarganegaraan anak yang lahir hasil perkawinan campuran mengikuti kewarganegaraan ayahnya sesuai Pasal 13 ayat 1 yang menyatakan:

"Anak yang belum berumur 18 tahun dan belum kawin yang mempunyai hubungan hukum kekeluargaan dengan ayahnya sebelum ayah itu memperoleh kewarganegaraan Republik Indonesia, turut memperoleh kewarganegaraan Republik Indonesia setelah ia bermukim dan berada di Indonesia. Keterangan mengenai bertempat tinggal dan berada di Indonesia tidak berlaku terhadap anak-anak yang ayahnya memperoleh kewarganegaraan Republik Indonesia menjadi tanpa kewarganegaraan."

Berdasarkan ketentuan UU Kewarganegaraan Lama, anak yang lahir dari perkawinan campuran bisa menjadi WNI dan bisa menjadi WNA. Bila seorang anak lahir dari perkawinan antara seorang wanita WNA dengan pria WNI, sesuai Pasal 1 huruf b UU Kewarganegaraan Lama, kewarganegaraan anak mengikuti ayahnya, yaitu anak menjadi WNI, bila ibu dapat memberikan kewarganegaraannya kepada si anak maka anak tersebut kehilangan kewarganegaraan Indonesia. Sebaliknya bila anak yang lahir dalam perkawinan antara wanita WNI dan pria WNA, maka anak menjadi WNA mengikuti ayahnya.

Bilamana anak tersebut lahir serta bermukim di Indonesia, maka terhadap anak tersebut harus dibuatkan paspor di Kedutaan Besar ayahnya serta harus mendapat Kartu Izin Tinggal Sementara (KITAS) yang harus terus diperpanjang serta memerlukan biaya yang mahal.

Bila terjadi perceraian antara ayah dan ibunya dan anak tetap di bawah pengasuhan ibunya yang WNI, maka sewaktu-waktu anak dapat di deportasi. Bila si ibu tidak sanggup membayar biaya perpanjangan 
KITAS bagi anaknya dan bila terjadi overstay lebih dari 2 bulan si ibu dapat dipenjara kurungan karena memberi makan dan melindungi orang asing sesuai Pasal 52 Undang-Undang Imigrasi No. 9 Tahun 1992 seperti yang terjadi di Jawa Timur dalam kasus Andreya Miyakoshi.

Dalam kasus ini, perempuan WNI yang bernama Atik menikah dengan pria warga negara Jepang. Dalam perkawinan tersebut lahirlah seorang anak perempuan bernama Anreya Miyakoshi. Berdasarkan UU Kewarganegaraan Lama, Andreya Miyakoshi memperoleh kewarganegaraan ayahnya yaitu Jepang. Pasangan ini kemudian bercerai dan pemeliharaan Andreya Miyakoshi diserahkan kepada ibunya. Akan tetapi karena terjadi overstay selama tujuh bulan maka si anak yang baru berusia 4 tahun harus di deportasi. Pada waktu itu jalan keluar yang disarankan oleh Kantor Imigrasi yaitu si ibu harus membawa anaknya ke luar negeri, ke negara mana saja, entah beberapa hari, setelah kembali baru surat-suratnya diperbaharui dan dianggap sebagai pendatang baru. Namun masalah yang dihadapi Ibu Atik yaitu sang ibu tidak mempunyai cukup uang untuk membawa anaknya ke luar negeri (Zulfa Djoko Basuki, 2005:129).

Dalam prakteknya, UU Kewarganegaraan Lama banyak menimbulkan kerugian bagi wanita WNI yang menikah dengan pria WNA, yang mana menurut hasil survey online yang dilakukan oleh Indo-MC (Indonesia Mixedcouple Club) dalam Tahun 2002 dari 574 responden yang terjaring 95,19\% adalah perempuan WNI yang menikah dengan pria WNA (Nuning Hallet, www.snb.or.id:1).

Kegetiran yang dialami oleh perempuan WNI dimulai ketika anak yang lahir dari rahimnya oleh negara diklaim sebagai WNA, ini berarti sang bayi diperlakukan sama dengan turis atau pebisnis asing. Ia harus melengkapi dirinya dengan paspor asing dan dokumen keimigrasian jika berada di wilayah Republik Indonesia, yang mana merupakan kampung halaman ibunya. Lahirnya anak dengan status asing inilah yang menjadi momentum dari segala kerumitan yang dihadapi sang ibu WNI selama hidupnya.

Kasus lain yang juga menimpa wanita WNI yang menikah dengan pria WNA, yaitu Eva Van Der Kruit yang tinggal di Belanda dan hendak mencoba keluar dari perkawinan yang menurutnya tidak sehat. Dia pulang ke Indonesia dengan membawa ketiga anak kandungnya, sayang kemarahan sang suami tidak terbendung dan melaporkan istrinya sebagai penculik warga negara Belanda dan dilaporkan ke Interpol.

Kasus lain dialami oleh Marcellina Tanuhandaru WNI yang menikah dengan seorang pria warga negara
Amerika di Kantor Catatan Sipil Colombus, Ohio, dari perkawinannya lahir 2 orang anak, keduanya lahir di Amerika, kedua anaknya warga negara Amerika. Namun karena Kekerasan Dalam Rumah Tangga (KDRT) yang dialami oleh Marcellina Tanuhandaru, maka ia bersama anak-anaknya pergi meninggalkan suami dan rumah di Colombus dan selama 2 bulan bersembunyi dalam shelter perlindungan di Colombus sesuai saran Konjen setempat, kemudian melanjutkan ke Washington untuk mengurus surat-surat di KBRI. Selama sebulan di KBRI mereka berpindah-pindah tempat tinggal sampai 5 kali supaya tidak bisa dilacak oleh suaminya. Setelah memperoleh kemudahan berupa Surat Perjalanan Laksana Paspor dari KBRI di Washington, akhirnya Marcellina beserta anakanaknya dapat meninggalkan Amerika dan pulang ke Indonesia. Di Indonesia masalah yang dihadapi Marcellina sebagai WNI yaitu ia harus mengurus izin tinggal dan membuat paspor Amerika bagi anakanaknya yang WNA, namun Marcellina bisa dituduh sebagai penculik anak Amerika bila ia mengurus paspor anaknya ke Kedutaan Amerika (Newsletter Perempuan, www.icrp-online.org).

Masih banyak kasus-kasus yang merugikan wanita WNI serta anak-anaknya dalam suatu perkawinan campuran, namun kasus-kasus tersebut di atas sudah cukup menggambarkan bahwa UU Kewarganegaraan Lama tidak akomodatif terhadap perempuan WNI dan anak-anaknya dalam perkawinan campuran.

\section{Status Kewarganegaraan Anak Berdasarkan UU Kewarganegaraan Baru}

Tertanggal 1 Agustus Tahun 2006 diundangkan UU Kewarganegaraan Baru yang mana menggantikan UU Kewarganegaraan Lama. Kehadiran akan UU Kewarganegaraan Baru itu disambut penuh antusias oleh para pelaku perkawinan campuran, karena anakanak yang lahir dari suatu perkawinan campuran tetap diakui sebagai WNI di samping kewarganegaraan asingnya yang mengikuti ayahnya atau dengan kata lain anak-anak hasil perkawinan campuran dapat memperoleh kewarganegaraan ganda.

Dalam Pasal 4 huruf c UU Kewarganegaraan Baru menyatakan:

"Warga Negara Indonesia adalah: anak yang lahir dari perkawinan yang sah dari seorang ayah Warga Negara Indonesia dan Ibu Warga Negara Asing"

Selanjutnya, Pasal 4 huruf d menyatakan:

"Warga Negara Indonesia adalah anak yang lahir dari perkawinan yang sah dari seorang ayah Warga Negara Asing dan ibu Warga Negara Indonesia"

Selanjutnya dalam Pasal 6 ayat 1 menyatakan:

"Dalam hal status Kewarganegaraan Republik Indonesia 
terhadap anak sebagaimana dimaksud dalam Pasal 4 huruf $c$, huruf d, huruf h, huruf $i$ dan Pasal 5 berakibat anak berkewarganegaraan ganda, setelah 18 (delapan belas) tahun atau sudah kawin anak tersebut harus menyatakan memilih salah satu kewarganegaraannya".

Dari Pasal 6 ayat 1 UU Kewarganegaraan Baru tersebut di atas maka kewarganegaraan ganda anak dalam suatu perkawinan campuran bersifat terbatas sampai pada usia 18 tahun saja, kemudian dia diberi waktu 3 tahun untuk memilih apakah akan menjadi WNI atau WNA.

Terhadap anak-anak yang lahir sebelum UndangUndang ini diundangkan, mereka dapat memperoleh kewarganegaraan ganda atau dapat menjadi WNA. Mereka dapat memperoleh kewarganegaraan ganda, bila orangtua atau walinya mendaftarkan mereka kepada Menteri melalui Pejabat atau Perwakilan Republik Indonesia paling lambat 4 (empat) tahun setelah Undang-Undang ini diundangkan. Dengan didaftarkannya anak-anak tersebut, maka mereka memperoleh Surat Keputusan dari Menteri Hukum dan HAM bahwa mereka adalah WNI. Bila sampai dengan Tahun 2010 anak-anak tersebut tidak didaftarkan maka mereka dianggap sebagai WNA (wawancara dengan Bapak Nengak Mahardika, Divisi Pelayanan Hukum dan HAM, Kanwil Hukum dan HAM Propinsi Jatim, periksa Pasal 41 UU No. 12 Tahun 2006 jo. Permen Hukum dan HAM No. M.01-HL.03.01 Tahun 2006 tentang Tata Cara Pendaftaran Anak untuk Memperoleh Kewarganegaraan RI). Sedangkan anakanak yang lahir di Indonesia setelah Undang-Undang ini diundangkan, pencatatan dilakukan pada Kantor Kependudukan dan Catatan Sipil dan memperoleh akte kelahiran sebagai WNI.

Masalah kewarganegaraan seseorang tidak hanya terbatas pada paspor serta izin tinggal di suatu negara tetapi mempunyai implikasi yang lebih jauh yaitu juga meliputi hak-hak dan kewajiban sebagai warga negara yang harus dijalaninya. Dalam Hukum Perdata Internasional Indonesia sebagaimana tertuang dalam pasal $16 \mathrm{AB}$ bahwa kewarganegaraan seseorang menentukan hukum yang berlaku baginya di bidang status personal yaitu meliputi hubungan-hubungan kekeluargaan seperti hubungan antara suami istri, ayah dan anak, perwalian termasuk soal-soal yang bertalian dengan perkawinan, pembatalan perkawinan, perceraian, status di bawah umur dan lain-lain.

Bila seseorang berkewarganegaraan asing, maka terhadap status personalnya berlaku hukum asing yaitu hukum nasional dari negaranya. Bila anak tersebut berkewarganegaraan ganda, maka anak tersebut tunduk pada dua yurisdiksi dari dua negara yang berbeda, sehingga asas kewarganegaraan yang dianut dalam
Hukum Perdata Internasional Indonesia melalui Pasal 16 AB sulit diterapkan terhadap kasus-kasus yang berkaitan dengan status personalnya.

\section{Hak-hak Perdata Anak Berkewarganegaraan Ganda dalam Hal Status Personal Anak sebagai Subjek Hukum}

UU Kewarganegaraan Baru tidak memberikan definisi mengenai apa yang dimaksudkan dengan anak, namun Pasal 6 ayat 1 disebutkan bahwa anak yang berkewarganegaraan ganda, setelah berusia 18 (delapan belas) tahun atau sudah kawin, anak tersebut harus memilih salah satu dari kewarganegaraannya. Berdasarkan ketentuan Pasal 6 ayat 1 tersebut di atas, batasan usia seorang anak adalah 18 tahun, bila sebelum 18 tahun anak tersebut telah menikah misalnya pada usia 14 tahun maka ia dianggap telah dewasa.

Dalam Pasal 47 ayat 1 UUP, juga ditegaskan batasan usia seorang anak adalah 18 tahun. Pasal tersebut menyatakan "Anak yang belum mencapai umur 18 (delapan belas) tahun atau belum pernah melangsungkan perkawinan ada di bawah kekuasaan orangtuanya, selama mereka tidak atau belum dicabut dari kekuasaannya"

Sejalan dengan adanya ketentuan usia 18 tahun bagi seorang anak, Undang-Undang No. 23 Tahun 2002 tentang Perlindungan Anak lebih jelas memberikan definisi tentang anak yang diatur dalam Pasal 1 angka 1 sebagai berikut:

"Anak adalah seseorang yang belum genap berusia 18 (delapan belas) tahun termasuk anak yang masih dalam kandungan"

Berdasarkan ketentuan-ketentuan tersebut di atas, kesimpulan yang dapat ditarik bahwa batas usia seseorang yang dianggap sebagai anak di Indonesia adalah 18 (delapan belas) tahun atau sudah kawin.

Dalam Hukum Perdata, manusia memiliki status sebagai subjek hukum sejak ia dilahirkan, kecuali apa yang diatur dalam Pasal 2 BW bahwa anak yang masih berada dalam kandungan dapat menjadi subjek hukum bila ada kepentingan yang menghendaki dan dilahirkan dalam keadaan hidup. Manusia sebagai subjek hukum berarti manusia memiliki hak dan kewajiban dalam lalu lintas hukum, namun untuk anak sebagai pendukung hak dan kewajiban, selama anak tersebut belum dewasa atau belum kawin, pada umumnya anak hanya mempunyai hak dan belum mempunyai kewajiban, sehingga mereka lebih banyak mendapat keuntungan akibat kewarganegaraan ganda. Oleh sebab itu bila mereka telah dewasa atau sudah kawin mereka harus memilih salah satu di antara 
kewarganegaraan ganda tersebut. Bila mereka tidak memilih salah satu dari kedua kewarganegaraannya maka mereka dianggap sebagai orang asing.

\section{Hak Anak dalam Bidang Hukum Perkawinan}

Berdasarkan data yang diperoleh pada Kantor Dinas Kependudukan dan Catatan Sipil Kotamadya Surabaya, dalam tahun 2009 sampai pada bulan Oktober terdapat 34 pasangan perkawinan campuran yang melangsungkan perkawinan campuran disana. Dari 34 pasangan tersebut, 29 pasangan diantaranya adalah perempuan WNI yang menikah dengan Pria WNA, sedangkan hanya 5 pasangan antara perempuan WNA yang menikah dengan pria WNI. Hal itu berarti sebanyak $85 \%$ pelaku perkawinan campuran adalah perempuan WNI.

Tabel Pelaksanaan Perkawinan Campuran di Kantor Dinas Kependudukan dan Catatan Sipil Kotamadya Surabaya (2009)

\begin{tabular}{cccc}
\hline Jumlah & Wanita & Pria & Prosentase \\
\hline 34 & WNI & WNA & \\
& 29 & 29 & $(85 \%)$ \\
& & & \\
& WNA & WNI & $(15 \%)$ \\
\hline
\end{tabular}

Data diperoleh tanggal 28 Oktober 2009.

Data tersebut tidak jauh berbeda dengan hasil penelitian Indonesian-Mixcouple Club (Indo-MC) baik melalui survey online yaitu pada tahun 2000, dari 574 responden yang terjaring $95,19 \%$ pelaku perkawinan campuran adalah perempuan WNI yang menikah dengan pria WNA. Hal yang sama ditemui pada Kantor Catatan Sipil DKI Jakarta dalam tahun 2002 sampai 2004 sebanyak 878 perkawinan campuran, $94,4 \%$ adalah perempuan WNI yang menikah dengan pria WNA (nuninghallet.multiply.com).

Pasal 7 ayat 1 UUP mensyaratkan umur seorang pria untuk dapat melangsungkan perkawinan yaitu telah mencapai usia 19 tahun dan pihak wanita telah berusia 16 tahun.

Bilamana seorang anak perempuan dengan status kewarganegaraan ganda hendak menikah pada usia 16 atau 17 tahun, maka anak tersebut tunduk pada syarat-syarat perkawinan dari negara mana, apakah syarat-syarat perkawinan menurut hukum Indonesia sebagaimana yang terdapat dalam UUP atau syaratsyarat perkawinan menurut hukum dari negara asing sesuai kewarganegaraan ganda yang diembannya.

Memang dalam Hukum Perdata Internasional, kewarganegaraan ganda merupakan masalah yang dihadapi oleh negara-negara yang menganut asas nasionalitas atau kewarganegaraan dalam menentukan hukum yang berlaku atas status personal seseorang.
Dalam literatur Hukum Perdata Internasional terdapat banyak pendapat mengenai jalan keluar atas masalah kewarganegaraan ganda yang dihadapi oleh negara-negara yang menganut asas nasionalitas atau kewarganegaraan untuk menentukan hukum yang berlaku atas status personal seseorang sebagai berikut (Sudargo Gautama 2, 1979:240-257): 1. Penulispenulis seperti van Brakel, Hijmans dan Kosters menyetujui dipakainya "lex fori" yaitu hukum dari forum hakim dimana perkara itu diajukan, karena hakim lebih mengenal hukumnya sendiri; 2 . Pendapat lain berasal dari Makarov dan Murad Ferid juga De Groot, menurut mereka penggunaan "lex fori" lebih diutamakan pada bidang hukum publik, dan di bidang Hukum Perdata Internasional mereka lebih condong untuk mencari apa yang dinamakan "nationalitet yang efektif". Jadi disini tugas hakim yang harus mencari tahu akan orang-orang yang punya kewarganegaraan ganda, kewarganegaraan manakah yang paling efektif atau hidup bagi yang bersangkutan.

Terhadap asas nasionalitas yang efektif, telah diterapkan dalam contoh kasus sebagai berikut: Kasus Nottebohm yang diputus oleh International Court of Justice pada tanggal 6 April 1955 (Zulfa Djoko Basuki, 2005:123). Dalam kasus ini menurut pendapat International Court of Justice bahwa seseorang yang mempunyai dwi atau multi-kewarganegaraan harus diperhatikan unsur-unsur yang dapat menentukan apa yang merupakan "real and effective nationality" antara lain, tempat kediaman yang bersangkutan, pusat kepentingannya, hubungan kekeluargaannya, turut serta dalam kehidupan sosial dan kenegaraan atau dengan kata lain harus diperhatikan seluruh kehidupan sehari-hari dari yang bersangkutan dalam kenyataan sosial" (Sudargo Gautama 3, 1964:194-198).

Putusan Hoge Raad tanggal 9 Desember 1965 yang dikenal dengan kasus "Noorse Echtscheiding" dimana istri mempunyai kewarganegaraan ganda yaitu Norwegia dan Belanda. Untuk menentukan hukum yang berlaku atas perceraiannya dengan suaminya warga negara Belanda, dipakai hukum Norwegia yang merupakan kewarganegaraan yang effektif dari istrinya. Putusan ini diinspirasikan dari kasus Nottembohm yang diputuskan oleh International Court of Justice 6 April 1965 (Rooij Van Rene, Maurice V. Polak,1991:53).

Hukum domisili yang dipakai untuk menentukan status personal seseorang yang berkewarganegaraan ganda. Dalam Hukum Perdata Internasional, sesorang bertempat tinggal dengan alamat di suatu kota adalah tidak penting, karena yang menjadi ukuran domisili sebagai tempat tinggal, adalah negara dimana ia 
berdomisili, berdasarkan domisili di negara tersebut, maka hukum dari negara tersebut berlaku untuk status personalnya. Hukum domisili yang jatuh bersamaan dengan salah satu kewarganegaraannya. Menurut beberapa penulis seperti Koster, Van Brakel dan Wollf, bahwa domisili yang jatuh bersamaan dengan salah satu kewarganegaraan dianggap sebagai bukti nyata adanya nasionalitas yang efektif (Sudargo Gautama 2, 1979:254).

Anak dengan kewarganegaraan ganda yang hendak menikah dalam suatu wilayah Republik Indonesia, maka ia harus memenuhi syarat-syarat perkawinan sesuai hukum yang berlaku di Indonesia yaitu UUP dan peraturan pelaksanaannya. Di Indonesia bila seseorang hendak melangsungkan perkawinan maka keinginannya harus diberitahukan kepada pegawai pencatat di tempat perkawinan akan dilangsungkan sesuai agama yang dianut. Pemberitahuan dapat dilakukan secara lisan ataupun tertulis oleh calon mempelai atau orangtua atau wakilnya.

Pemberitahuan tentang pelaksanaan perkawinan harus memuat nama, umur, agama atau kepercayaan, pekerjaan, tempat kediaman calon mempelai. Untuk membuktikan umur calon mempelai harus disertai kutipan akte kelahiran atau akte kenal lahir calon mempelai, bila tidak ada akte kelahiran atau surat kenal lahir maka dapat digunakan surat keterangan dari Kepala Desa atau Kelurahan yang menerangkan tentang umur dan asal-usul calon mempelai.

Selain keterangan mengenai para calon mempelai, diperlukan juga keterangan mengenai orangtuanya, yaitu tentang nama orangtua, agama atau kepercayaan, pekerjaan dan/atau tempat tinggal orangtua calon mempelai (Pasal 4, 5, 6 PP No. 9 Tahun 1975). Bila calon mempelai tinggal di luar negeri, maka harus ada keterangan dari Perwakilan Indonesia di negara tempat tinggalnya bahwa calon mempelai tersebut tidak ada halangan-halangan untuk melangsungkan perkawinan.

Oleh sebab itu bila anak yang berkewarganegaraan ganda hendak menikah di Indonesia, bila ia berdomisili atau mempunyai habitual residence di Indonesia maka hukum Indonesia yang berlaku terhadapnya. Akan tetapi bila anak yang berkewarganegaraan ganda mempunyai habitual residence di luar negeri, maka terhadap anak tersebut diperlakukan sebagai WNA (wawancara dengan Bapak Sianipar pada Kantor Dinas Kependudukan dan Catatan Sipil Kotamadya Surabaya).

Dalam pemahaman Hukum Perdata Internasional seseorang yang mempunyai habitual residence yaitu orang tersebut secara fakta bertempat tinggal di suatu negara, fakta tersebut dapat berupa rumah, atau tempat pekerjaan di negara tersebut. Namun oleh karena anak yang belum dewasa atau belum kawin pada umumnya tempat tinggalnya mengikuti orangtuanya, dan bila tempat tinggal orangtuanya di Indonesia maka habitual residence anak tersebut adalah di Indonesia.

Pemecahan terhadap permasalahan status personal seorang anak yang berkewarganegaraan ganda sebagai akibat diberlakukannya UU Kewarganegaraan Baru, selaras dengan pendapat dari Koster, Van Brakel dan Wollf yaitu terhadap mereka dipakai hukum domisili yang jatuh bersamaan dengan salah satu kewarganegaraannya. Hal mana merupakan bukti yang nyata sebagai nasionalitas yang efektif sebagaimana telah diterapkan dalam kasus Nottebohm dan Noorse Echtscheiding di Belanda.

\section{Hak Anak Berkewarganegaraan Ganda sebagai Ahli Waris}

Menurut teori Hukum Perdata Internasional, untuk menentukan status anak dalam hubungan antara anak dan orangtua, perlu dilihat terlebih dahulu perkawinan orangtuanya sebagai persoalan pendahuluan, apakah perkawinan orangtuanya sah, sehingga anak memiliki hubungan hukum dengan ayahnya, bila perkawinan orangtuanya tidak sah, maka anak hanya mempunyai hubungan hukum dengan ibunya.

Dalam hukum waris yang berlaku di Indonesia, anak adalah ahli waris, dengan catatan dalam hukum waris Islam anak yang dimaksud harus ada hubungan darah dengan orangtuanya.

Berdasarkan UU Kewarganegaraan Lama, anak yang lahir dari suatu perkawinan campuran, bila ayahnya WNA dan ibunya WNI maka status anak menjadi WNA mengikuti ayahnya sesuai Pasal 13. Setelah berlakunya UU Kewarganegaraan Baru, anak memperoleh kewarganegaraan ganda terbatas.

Sebelum UU Kewarganegaraan Baru disahkan, yaitu pada saat rancangan undang-undang tersebut dibahas pada tingkat Dewan Perwakilan Rakyat, banyak masukan yang diperoleh dari para pelaku perkawinan campuran mengenai kegetiran-kegetiran yang telah mereka alami pada waktu berlakunya UU Kewarganegaraan Lama.

Salah satu kasus yang muncul melalui media internet, yaitu sebagai berikut, pasangan suami-istri yang terikat dalam suatu perkawinan campuran, istri WNI sedangkan suaminya WNA. Pasangan ini telah menikah selama 20 tahun dan berdomisili di Indonesia. Setelah perkawinan, istri tetap menjadi WNI kemudian sang istri meninggal karena sakit kanker. Akan tetapi sepeninggal istri, suaminya dan 
anak-anak yang WNA tidak dapat mewarisi rumah milik istri dan ibunya anak-anak karena status mereka adalah WNA. Menurut ketentuan Hukum Agraria di Indonesia, harta kepemilikan tersebut harus dijual dalam waktu satu tahun, dan hasil penjualan dibagi menjadi dua, yaitu untuk negara dan para ahli waris (www.nuninghallet.multiply.com).

Di Indonesia untuk memperoleh hak-hak atas tanah dibatasi bagi orang asing, antara lain: hak milik; hak guna bangunan tidak dapat dimiliki oleh orang asing sesuai UUPA dan peraturan pelaksanaannya. Seiring dengan diberlakukannya kewarganegaraan ganda bagi anak-anak hasil perkawinan campuran, yang mana salah satu kewarganegaraannya adalah sebagai WNI dan yang menjadi masalah apakah anak-anak yang berkewarganegaraan ganda dapat merealisasikan haknya di bidang hukum tanah.

Di Indonesia sejak diundangkannya UUPA, Pasal 21 ayat 2 melarang WNA untuk memperoleh hak milik atas tanah, bahkan ayat 3 melarang seorang yang mempunyai kewarganegaraan ganda untuk memperoleh hak milik. Sedangkan terhadap Hak Guna Bangunan, sesuai Pasal 36 UUPA jo. Pasal 19 PP No. 40 Tahun 1996, disebutkan bahwa hak guna bangunan hanya diberikan kepada WNI. Hakhak atas tanah yang dapat dimiliki oleh WNA hanya hak pakai.

Setelah diundangkannya UU Kewarganegaraan Baru, maka peraturan di bidang agraria belum berubah, sehingga anak-anak yang berkewarganegaraan ganda sulit untuk merealisasikan haknya, dalam arti memiliki hak-hak atas tanah yang ditinggalkan oleh salah satu orangtuanya yang berkewarganegaraan Indonesia.

Bilamana anak yang berkewarganegaraan ganda memperoleh warisan dari salah satu orangtuanya berupa tanah hak milik, maka hak anak tersebut tentunya tidak hapus. Akan tetapi ia harus menunggu sampai usianya mencapai 18 (delapan belas) tahun, kemudian memilih menjadi WNI barulah ia dapat memiliki haknya sesuai peraturan yang berlaku.

Alternatif lain yang dapat ditempuh oleh anakanak yang berkewarganegaraan ganda yaitu melalui penurunan hak, misalnya dari hak milik menjadi hak pakai, namun dalam praktek cara ini jarang dipakai (wawancara dengan Ibu Ida, Kepala Bagian HakHak atas Tanah, Badan Pertanahan Nasional Propinsi Jawa Timur).

\section{PENUTUP}

\section{Kesimpulan}

Kewarganegaraan ganda anak dalam perkawinan campuran sebagai akibat dari diundangkannya UU
Kewarganegaraan Baru, membawa implikasi dalam Hukum Perdata Internasional yaitu mengenai status personal anak tersebut tunduk pada hukum dari negara mana. Dalam Hukum Perdata Internasional yang berlaku di Indonesia, kewarganegaraan seseorang menentukan hukum yang berlaku baginya di bidang status personal sesuai Pasal 16 AB. Terhadap anakanak berkewarganegaraan ganda, dengan memiliki paspor sebagai WNI belum cukup diterapkan hukum Indonesia terhadap status personalnya, bila anak tersebut tidak berdomisili dalam arti mempunyai habitual residence di Indonesia. Oleh sebab itu, terhadap anak yang mempunyai kewarganegaraan ganda, status personalnya diatur oleh hukum domisili dalam arti habitual residence anak tersebut yang jatuh bersamaan dengan kewarganegaraan Indonesia. Bila anak yang berkewarganegaraan ganda mempunyai domisili di luar negeri dan hendak menikah di dalam wilayah Republik Indonesia, ia diperlakukan sama dengan WNA.

Bilamana anak yang berkewarganegaraan ganda memperoleh warisan hak atas tanah berupa hak milik, maka anak tersebut harus menunggu sampai usianya 18 (delapan belas) tahun dan ia memilih menjadi WNI barulah ia dapat merealisasikan haknya sesuai peraturan yang berlaku. Karena hak milik merupakan hak yang paling kuat dan tidak hapus dalam jangka waktu yang singkat. Terhadap hak guna bangunan karena jangka waktunya terbatas, maka jalan keluar yang dapat ditempuh yaitu dengan jalan diturunkan tingkatnya menjadi hak pakai bila diperlukan.

\section{Rekomendasi}

Perlunya dibuat undang-undang di bidang Hukum Perdata Internasional yang dapat diberlakukan di Indonesia agar ada kepastian hukum terkait masalahmasalah Hukum Perdata Internasional di Indonesia, dan sebagai pegangan bagi para pelaksana hukum di Indonesia, serta adanya unifikasi pengaturan dalam menyelesaikan masalah yang berkaitan dengan Hukum Perdata Internasional.

\section{DAFTAR PUSTAKA}

\section{Buku:}

Basuki, Zulfa Djoko, 2005, Dampak Perkawinan Campuran terhadap Pemeliharaan Anak Ditinjau dari Segi Hukum Perdata Internasional, Jakarta: Yarsif Watampone.

Gautama, Sudargo, 1964, Hukum Perdata Internasional Indonesia, Jilid 2 Bag. 3, Jakarta: Kinta. , 1979, Hukum Perdata Internasional

Indonesia, Jilid 2 Bag. 1, Bandung: Eresco. 
, 1981, Hukum Perdata Internasional Indonesia, Jilid 3 Bag. 1, Bandung: Alumni.

Harsono, Budi, 1975, Undang-Undang Pokok Agraria, Sejarah Penyusunan, Isi dan Pelaksanannya, Jakarta: Djambatan.

Manan, Bagir, 2009, Hukum Kewarganegaraan Indonesia dalam UU No. 12 Tahun 2006, Cetakan Pertama, Jakarta: FH UII Press

Rooij, Rene Van dan Polak V. Maurice, 1987, Private International Law In Netherlands, New York: Kluwer Law and Taxation Publishers.

Sudarsono, 1991, Hukum Perkawinan Nasional, Jakarta: Rineka Cipta.

T.M.C. Asser Instituut, 1991, Study Materiaal Internationaal Privaatrecht, Deel I, Algemeen Gedeelte Personen-en Familierecht Erfrecht, Maklu Uitgevers Antwerpen-Apeldoorn.

\section{Peraturan Perundang-Undangan:}

Undang-Undang No. 1 Tahun 1974 tentang Perkawinan.

Undang-Undang No. 5 Tahun 1960 tentang PokokPokok Peraturan Dasar Agraria.

Undang-Undang No. 12 Tahun 2006 tentang Kewarganegaraan Republik Indonesia.
Peraturan Pemerintah No. 9 Tahun 1975 tentang Pelaksanaan Undang-Undang No. 1 Tahun 1974 tentang Perkawinan.

Peraturan Menteri Hukum dan HAM Republik Indonesia No. M.01-HL.03.01 Tahun 2006 tentang Tata Cara Pendaftaran Anak untuk Memperoleh Kewarganegaraan Republik Indonesia.

Burgerlijk Wetboek terjemahan R. Subekti dan Tjitrosudibio, 2001, Pradnya Paramita, cetakan ke 21.

\section{Internet:}

www.snb.or.id

www.nuninghallett.multiply.com

www.icrp-online.org

\section{Wawancara:}

Bapak Nengak Mahardika, Divisi Pelayanan Hukum dan HAM, Kanwil Hukum dan HAM Propinsi Jawa Timur.

Bapak Sianipar, Kantor Dinas Kependudukan dan Catatan Sipil Kotamadya Surabaya.

Ibu Ida , Kepala Bagian Hak-Hak atas Tanah, Badan Pertanahan Nasional Propinsi Jawa Timur. 